Portland State University

PDXScholar

1976

\title{
A Holistic Approach to Social Work Education
}

Lynda M. Wright

Portland State University

Follow this and additional works at: https://pdxscholar.library.pdx.edu/open_access_etds

Part of the Social Work Commons

Let us know how access to this document benefits you.

\section{Recommended Citation}

Wright, Lynda M., "A Holistic Approach to Social Work Education" (1976). Dissertations and Theses. Paper 1867.

https://doi.org/10.15760/etd.1866

This Thesis is brought to you for free and open access. It has been accepted for inclusion in Dissertations and Theses by an authorized administrator of PDXScholar. Please contact us if we can make this document more accessible: pdxscholar@pdx.edu. 
A HOLISTIC APPROACH TO SOCLAL WORK EDUCATION

\section{by}

Liynda M. Wright

A Practicum Submitted in Partial Fulfijiment of the Requirement: For the Degree of

MASTERS OE SOCIATE WORK

Portiand State riniversity

1976 
B. John Hale, M.S.W., M.P.H.

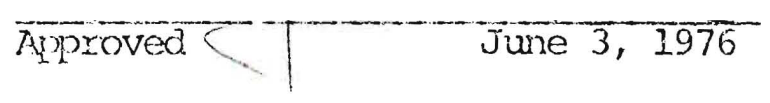




\section{ACKNONTEDCMENIS}

The research for this practicum began and continues through selfexploration. I would especially like to thank those people who have contributed to my personal growth during the past year.

Special thanks goes to my practicum advisor, B. John Yiale, for his enthusiastic support and encouraganent in this endeavor.

My husband, Thomas, has always been my besti critic. Iis constructive criticism and proofreading aided in the achievement of a more unified product. I am grateful to my husband and our cinildren, Brian and Andrea, for their continuing love and understanding.

Special acknowledgement goes to the following people: to Charlene Afremor, who as a facilitator for Iifespring assisted me in experiencing ny power and strengths; to Verme Davis, Executive Director of the Mental Ilealth Association, whose philosophy and humanistic supervision aided in the expansion of my awareness; to Judith Garrison, my close Exiend, who

increased my understanding of the metaphysical realm; to Gjsèle Fitch, my Yoga teacher, who is an inspiration in ljwing and expansion: to Robert Brodwell, N.D., who introducel me to homeopatiolo healing methods that work; and to Jack Schirartz whose guidälce showed ne how to use a holistic attitude in the realization of my potentialjties. 
TABLE OE CONTENTS

PAGE

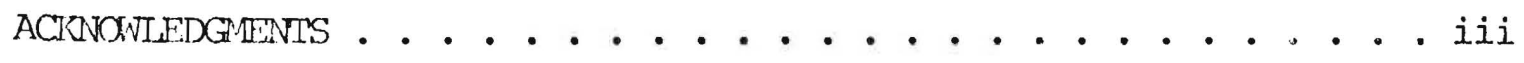
CHAPTER

I. FACING CHAINGE . . . . . . . . . . . . . . . . 1

The Stress Around Us . . . . . . . . . . . . . 1

Helping Others Adjust. . . . . . . . . . . . 4

The Need to Develop Fmpathy . . . . . . . , 5

The Need for Self-Awareness . . . . . . . . . 6

The Hazards of Rescuing . . . . . . . . . . 8

The Value of Self-Experience . . . . . . . 10

The Needs of Students . . . . . . . . . . 12

The Needs of Professionals . . . . . . . . . 14

Implications for Curriculum Expansion . . . . . . . 14

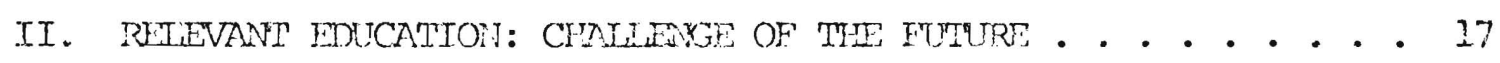

Trends in Graduate Education . . . . . . . . . . 17

The Contribution of Confiluent Education . . . . . . 19

How Students Can Realiy Learn... . . . . . . 20

Why Encounter . . . . . . . . . . . . 22

Toward Curriculum Expansion . . . . . . . . . 23

III. MIND-BODYGIRTI . . . . . . . . . . . . . 25

Holistic Education . . . . . . . . . . . 25

1 Holon . . . . . . . . . . . . . 25 
Natural-System Model . . . . . . . . . . 26

Holism and Social Work . . . . . . . . . . 26

Mind-Body-Spirit . . . . . . . . . . . . . 28

1. Psychosynthesis . . . . . . . . . 30

2. Gestalt Therapy . . . . . . . . . . 31

3. Hatha Yoga . . . . . . . . . . . 32

4. Breathing Therapy . . . . . . . . . . 33

5. T'ai Chi Ch'uan . . . . . . . . . . 33

6. Aikido . . . . . . . . . . . . 34

7. Meditation ............... . . 34

8. Inner Imagery . . . . . . . . . . . . . . . . . . .

9. Structural Integration . . . . . . . . . 35

10. The Feldenkrais Method . . . . . . . . . 37

11. Bioenergetics . . . . . . . . . . . . 38

Growth and the Graduate Curriculum . . . . . . . . 39

BIBLIOGRAPHY . . . . . . . . . . . . . . . . . 41 


\section{CHAPTER I}

FACING CHANGE

My definition of "political" has now expanded to include the food we eat, the excitation in our bodies, how we raise our children. People out of touch with their own bodies cannot make a revolution. The political battles of the 1960 s included too many crazy meetings, bureaucratic hassles, ideological wars because people were not aware of their own need for personal growth. In the 1970s we are going imward and discovering that we are the creators of our experience. Soon the spiritual and political revolutions will be joined: the inner and the outer;

\section{The Stress Around Us}

The explosive riots of the sixties are illustrative of the serious stresses faced by large groups of people in our society. Crowded livirg conditions in ghetios, inadequate health care and nutritional deficiencies are a few of the obrious stressful conlitions fact by the poor.

Nor are the poor by ariy means alone in having to cope with stressful conditions. In the United States over half of all deachs occur because of heart ana circulatory diseases. Hypertension is a stress related disease affecting over one-third of the adilt male population. In attermts to combat stress, millions of Americans are tuming to silecping pills, tramuilizers, amphetamines, alcohol, cigarettes and illegal drugs. ${ }^{2}$

IJersy, Rubin, "From the Streets to the Body," Psychology Today, (Septenber 1973), p. 71.

2Haxold H. Blcomield et al., TM: Discovering Inner Energy and Overcoming Stress (New York: Dell Publishing Co., Inc., 1975), pp. 29-30. 
America has long been idolized as the richest country in the world in terms of material wealth. The vast majority of Americans, however, have not learned how to achieve and maintain balance between their physical, mental and spiritual development in everyday living. Consequently Americans feel victimized by their own overindulgence. Alienation and lack of purpose in living are common among all classes and races of people in the United States.

This lack of personal satisfaction is delineated by Geri Metz:

This mental illness in civilized societies is so generalized and widespread that it goes unroticed in 211 but its most extreme manifestations. The allergits, the headaches, the "comm mon" colds, the acid indigestions, the constipations, the booies pulled out of shape by misular tension - all these are considered "normal" and not serious. Somewhat incre advancer symptoms such as ulcers, early heart attacks, mocerate alconoiism, mod-.. erate drug abuse (and tris definitely includes the trancuilized housavife and business executive) -- these are unfortunate, but still within the acceptable. Further along is the occasional individual whose symptoms, perhaps very controlled for the most part, one day explode into an orgy of anger resulting in the nurder of innocent victims; or the schizophrenic, withdrawn into his own world. And we don't even mention the general unhappiness and discontent etched into the faces of civilized man, or the suicicie, the broken homes, the ceaseless drive for more, the lack of satisfaction.

The saddest part of this sad picture is that we accept most of it as the rorm and that we allow our society to perpetuate tha sickness.

- . Western man needs a new awareness of his wholeness, of his complex union of body, mind, and emotions. . .3

Rapid and often unexpectexi change weakens the physical functioning of the body and adversely affects tine emotional well-being of the person. In TM: Discovering Inner Energy and overcoming Stress, the authors explain the adverse effects of stress:

3 Geri Metz, "Gestalt and the Transformation," in The Live Classroom, ed. George Isaac Brown (New York: The Viking Press, 1975), pp. 19-20. 
The medical term for excessive wear and tear upon the body is stress. When a person is subjected to continuous change, his body must respond to this demanding circumstance. In adapting to circumstances which challenge his faculties, an individlal reacts biochemically and physiologically. This adaptacion process taxes the body's essential resources and exhausts its energies. Repeated exposure to excessive stress without sufficient rest to restore depleted bodily resources triggers a process of deterioration which undermines every aspect of a person's experience. When people begin to suffer from accumulated stress, they become susceptible to disease, particularly to psychosomatic ailments. They also find thenselves troubled by inexplicable anxiety, frustration, depression or a general feeling of dissatisfaction and aimlessness. When stress accumulates, a loss of mental clarity and emotional openness damages interpersonal relationships. Fxcessive stress also leads to the inability to make decisions, plan effectively and work efficiently. Because of the total interdependency of bodily, emotional and mental processes, stress affects every phase of one's life. 4

One of the most eminent authorities on stress in this country is Hans Selye. In his recent book, Stress without Distress, Seyle explains that activity associated with stress may be pleasant or unpleasant; but distress always refers to a disagreeable situaticn. Seyle feels that stress is not something to be avoided. In fact, he explains that complete freedon from stress is death. ${ }^{5}$ Attempts to avoid stress can be self-defeating because the resultant boredom can be more stressfull than the original pressures. A tour of any state mental hospital will give observers a graphic illustration of. this kind of stressful boredom.

To most effectively adapt to stress, Seyle suggests that instead of avoiding work, people should find the kind of occupation for themselves that is play. 6 This same philosophy was reflected by Yogi Joel

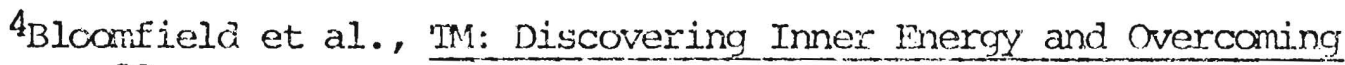
Stress, p. 29.

5 Hans Selye, Stress Without Distress (New York: Signet, 1974), pp. 19-20.

${ }^{6}$ Ibid. , p. 82. 
Kramer at a Yoga demonstration in Portland, Oregon held in April 1976. Kramer said adults can learn how to take care of thenselves by really watching children at play. During play children exert much energy, but no effort at all. Kramer believes that interest in what we are doing is the secret to satisfaction in life.

Helping Others Adjust

One of the most popular books dealing with change and the resultant stress is Future Shock by Alvin Toffler. He says the hope of the future lies in our ability to help others turn crises into opportunities.

The only way to maintain any semblance of equilibrium during the super-industrial revolution will be to meet invention with invention - to design new personal and social change-regulators. Thus we need neither blind acceptance nor blind resistance, but an array of creative strategies for shaping, deflecting, accelerating or decelerating change selectively. The individual needs new principles for pacing and planning his life along with a dramatically new kind of education. He may also need specific new technological aids to increase his adaptivity . . .7

As change agents in our "future shock" society, social workers need foremost to be equipped with tools for self-survival which they can share with their clients in facing the myriad problems of living. Fmanuel rropp urges social workers to return to emphasis on mutuality in helping others to help thenselves realize their potentials instead of relying upon diagnosis and treatment. Thopp explains:

. . excessive change in peoples' lives will increasingly have to becoms one of the concerns $c_{f}^{f}$ soctal work . . What generally has been either stated or implied is that the charge agent knows what changes raexl to occur and then devotes in.s efforts to effecting inin. ${ }^{\text {ह }}$

7 Alvin Tofflex, Future Shock (New York: Rantiam Books, 1970), p. 373.

8 Emanuel Tropp, "Approacijing the Concent of Change in Elucation for Social Work," Journal of Erzuration for Social tork (Spring 1973): 99-106. 

Thomas Wright is Administrative Director of Solo Center in Portland, Oregon. Long before obtaining his Masters in Social Work from Portland State University, Wright noted that social workers often react according to what socjety expects of them at the expense of their clients' desires. He explained:

The way a social worker can be an effective change agent is to first learn more about himself. What are his real motivations for being a change agent? That's the first thing he should know. This understanding would iriclude his real motivations for helping someone, too. In helping others a real understanding of waglking in that person's shoes - empathy - is very important.

The Need to Develop Empatty

"Empathy" is the word which best describes the kind of understandirs needed by social workers in professional practice. Accordjing to a study by Thomas Keefe, the value of empathy is needed by direct service workers and social planners alike. He says:

To facilitate interaction, cormmication, and behavior change the helping person must have high levels of empathy whether his intervention is at a micro or macrosystem level . . A capacity to know the true state of another is critical to successful intervention whether the context is a psychotherapeutic hour, a negotiation meeting with rebelling prisoners, or a board meeting discussing ajlocation of fiscal resources. ${ }^{10}$

In recent years social workers have begun to identify empathic skills of lay people in "natural helping netwonks" within various communities. These natural helping characteristics found among bartenders, beauticians, and some neighhowhood mothers are currently bejng studied

${ }^{9}$ Intervien with Thomas J. Wright, Portland, Oreyon, 22 May 1976.

10 Thomas keefe, "mpathy and social work Education: A Study," Journal of Education for Sociail Work (Fali 1975): 70. 
in much the same manner as an anthropologist studies a different culture in a foreign country.

Like anthropologists, social workers studying natural helping networks agree that these people must be left alone to function successfully in their natural enviroment. According to Diane Pancoast who teaches a social work class in natural helping networks, professional education is likely to contaminate the innate skills of these natural helpers.

Are empathic skills found in "nacurai helpers" somehow different from the empathic skills of professional social workers? Is empathy something that can be taught in a theoretical presentation by a professor in the classroom or is it a quality trat must be experienced to be fully understood.

The Need for Self-Awareness

Iaymen and clients have observed that social workers may have personal problens and biases which interfere in the helping relationship due to the social worker's lack of personal awareness. It is not inconceivm able, for instance, to find a social worker with a drinking problem working in an alcoholic rehabilitation program or to find an obese social worker involved in weight reduction counselling. In a therapeutic situation a social worker who is currently experiencing unresolved sexual problems is not in the best position to helo others with similar difficulties. The above examples are particularly true for those socjal workers who feel too uncomfortable to acknovledge their obvious personal adjustment problens to their clients. In many cases the social vorker feels he must protect his image and may hide behind the facade of his professional 
degree instead of expressing his true feelings to his clients.

Until recently this type of non-self disclosing behavior on the

part of the therapist was sanctioned under the guise of assuring objectivity and preventing the social worker from becoming too personally involved with his clients. Armitage and clark express this kind of professional separatism when they say:

- . the expressions of values in terms of professional practice behavior represents a desirable restriction in focus. In social work education one is not concerned with "the whole man", or with the student's personal, moral, or religious life, but with professional activity. In that the statement of values in performance-based terms restricts values to professional practice, it helps avoid cbjectives that appear manipulative of the student's total being. Il

The result of such "professional" attitudes as those held by Amitage and Clark is that few graduate schools prepare social workers to be comfortable wi.th their feelings or to be able to relate authentically to their cients.

The pitfalls of professional role playing are exemplified by Duane Tromas:

In my orm experience those I have encountered most concerned with professional roles seem to have the greatest difficuity with interpersonal relationships. At the same time they also seem to be the least effective within a therapoutic relationship. I feel that roles are artifacts; they invite distance; they serve to separate rather than to bring people together . 12

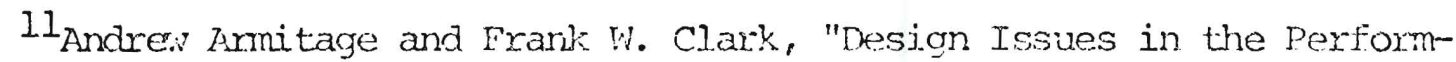
ance-Based Curriculum," Journal of Education for Social Work (Winter 1975): 25 .

12ivuane Thomas, "The Social Worker: as "Trainer," in Social Workers as Trainers in Health Programs, ed. Laura Bertino and Robert C. Jackson (Berkeley: University of Celifornia, 1972): 34. 
Thomas further explains the value in developing authentic relationshins with clients when he says the social worker:

- . must be willing to express his real feelings, examine his own activity within the relationship, engage in self disclosure; in short, respond to the trainee as a real person within a real situation. I am aware that this begins to rudge the sacred cow that has long roamed the pastures of social work practice, that is, the concept of a "professional relationship." In my view many antihuman practices have been perpetrated under this overall euphemism of "maintaining a professional relationship." In this respect I view with a jaurdiced eye concepts such as "maintaining emotional distance," "clinical detachment," "compassionate disinterest," and even the constant caution given by many not to "overidentify with the client." Iy attitude in this respect is not a general "rip-off" of the scientific approach that is necesssary in any sound practice. Human emotions and scientific: principles need not lock in moral combat. Thinking and feeling can be a simultaneous experience. It is my suspicion that overconcern with professional roles has had a much nore negative than positive effect on practice in general. 13

The Hazards of Rescuing

When the social worker is not comfortable with his own feelings, he is even less likely to be of real value to his clients in the therapeutic situation. The insecure social worker resorts to "rescuing" his cljents from uncomfortable situations. John 0 . Stevens has given the following criticisms of this all too common kind of "helping" prevelant among social workers:

One of the commonest (and also vidaly accepted) ways of not respecting a person's experience is to rush in with help when a person is foeling "bad" or uncomfortatile. Being "helpful" with reassurance, reassurance, jokes, confort, etc, prevents the person from fliily experiencing his grief. anger, aloreness, etc. Only through experiencing it fully can he accept it, assimilate it into his total ife experience, and grow into a more complete and integiated human being. Almost al-

13 Ibid. 
ways the "helper" actually helps himself by helping others. By rushing in with a band-aid, he stops the expression of feelings which are painful for him to feel. He also convinces himself and others that he is capable of helping others and doesn't need help himself. Almost every "helper" has strong feelings of helplessness which diminish tenporarily when he helps someone else. This is true of a great many people in the "helping" professions: teachers, psychologists, and especially social workers. . .

There is a widespread assumption that a person who is in difficulties is weak and needs help. In one sense this is true, because so much of his energy is spent in manipulation of himself and manipulation of others that he has very li.ttie energy left for direct coping with the world. If you "help" such a. person, you encourage him in his delusion that he needs you to help him, and you increase his investment in manipulating you to come to his rescue. But if you insist that he get more in touch with his own experience, he can come to realize the tremendous energy and power he expends in manipulating both himself and others in order to get support from others. As he assimilates this energy, he can learn to use it more directly for his own self-support. He can realize that he can do many things for himself that he previously thought he needed others to do for him. 14

Clark Moustakas has noted the importance of having the freedom to grow and to actualize one's potentials provides the best foundation fox interaction with others in both groups and society in general. when speaking of self-responsibility he explains:

Ultimately, I cannot be responsible for another person. I can only participate in his life, not matter what that participation may become to mean to him. But, in the end he discovers hi.s cwn meanings, his own resources, his own nature, his own being. . I5

The social worker actively engaged in "rescuing" should remind himself that each person involuntarily court comited to a state mental hospital is the end product of professionals who have decided how to

14 Iohn O. Stemhens, Awareness: Exploring, Experimenting, Experiencing (Lafayetre, California: Real people Press, 167i), pp. $128-129$.

${ }^{15}$ Clark Noustakas, Creativity and Conformity (New York: Van Nostrand Reinhola Company, 1967), p. 23. 
"help" someone who does not. want this king of "help". Massive dosages of tranquilizers and electroconvulsive therapy administered to mental patients against their will are but two more examples of societysanctioned rescuing behavior.

The "people-separating" behavior inherent in the psychiatric labeling system deserves careful scrutiny by social workers. Clark Moustakas speaks of the commonality of all mankind when he says:

Real understanding of the individual does not come from viewing the person as an object for analysis and study, from noting his behavior and probing into the so-called hidden dynamics, frustrations, and conflicts of his past life. Genuine unclerstanding is not a shrewd analysis which is disclosed by strange sions and symbols, not a clever diagnosis which has a keen eye for the weaknesses of people but rather it is rooted in life itself, in living with the other person, in being sensitive and aware of the center of a person's world, perceiving the essential nature of the person as he is, and respecting and valuing his resources and strengths. Orily when the person is reoognized as an integrated being with self-detemining resources is there hope tirat a unity of mankind can also be born. 16

The Value of Self-Experience

Self-help groups like La Ieche League and Weight watchers have long recognized the value of personal experience in developing the ability to help others with similax problerw. Peer counselling is used effectively by acjolescent groups and such dissimilax organizations as Parents Anonymous and Symanon. In North Dakota the Lutheran Family Sexvices has a FRIENDS Proyxam that. matches up people who have successfully experienced through a problem in living with othexs who are currently having sinilar djfficulties. In addition to problems like divorce, mental hospitaliza-

${ }^{16}$ Ibid. , p. 5. 
tion and widowhood, FRIENDS also does match-ups for people who have recently gone through bankruptcy or who are in less conmon states of transition.

People who ssek out self-help groups generally recognize the value of being able to relate to a person who is an effective role model because of personal success in the growth program. Before a person can qualify to be a lecturer for Weight watchers, for instance, he must first successfuly have dealt with his own weight problem and continue to demonstrate the ability to maintain his weight loss. The perspective lecturer is then given practical training in public speaking and is instructed in how to effectively conduct weekly classes to meet the needs of the members. It does not take much reasoning to understand why an obese member finds it easier to relate to a former fat person on a weekly basis than to a doctor who hands her a 1,000 calorie diet and expects that she will simply follow his advice without sufficient words of support.

The importance of self-awareness in working with groups is stressed by Willian C. Schutz. He explains that too many technically skilled group leaders never really excel because ". . . their own personal needs have intruded into the group -... perhaps sadism, ancer over rejection or lack of respect, passivity due to fear of failure and enbarrassment, defensiveness, or a need to be sexually attractive. . ."17 Schutz says group leaders should have a broad-ranged exposure to such experiential workshops as massage, gestalt training, mysticism, bioenergetics, yoga, meditation, and tai chi.

17 Wilitam C. Schutz, Hexe Cones Everybody (Nev York: Harper \& Row, Publishers, 1971), pp. 310-3il. 
Nan Narboe is a social worker who conducts growth workshops and therapy groups in the Portland area. For those interested in being therapists, Narboe gives the following suggestion: "At least half the time needs to be spent in personal therapy. I don't see any other way to be effective as a therapist. Besides, I don't feel right asking someone else to do something I wouldn't do."18

\section{The Needs of Students}

Students are admitted to graduate schools of social work under the assumption that the next two years will be spent improving cognitive skills in the academic classroom and practical skills through field placements in the community. Social workers are expected to help clients in stressful situations like poverty, divorce, and unemployment. oddly enough, virtually no training is available to the social worker to enable him to handle stress successfully in his own life.

Before the student even begins graduate work he is often faced with an inordinately high number of life changes that invoive mich stress. He may be required to move to a new city to attend school. He may have gone through a recent separation or divorce. have recently terminated enploymant. and/or have continuing family responsibilities. He maiy find he needs to work either part-time or ful.i-time to supplement his colieye loans or stipend during the same time he is expected to ourplete his graduate studies.

In addition to these personal problems faced by individual students, graduate school has built-in pressures that make this period one 
of the most strenuous times in the life of the professional. As the student continues his formal education he is faced with constant questions concerning his capabilities as a professional social worker. The endless stream of papers and tests necessary to fulfill course requirements are accompanied by demands for performance at his field placements. riany professors feel they must make strong academic demands on the student to assure fucure excellence in professional practice. Many times students feel social work is not supposed to be enjoyable, a belief held by Norman Wyers, the new coordinator of the undergraduate social work. program at Portland State University. Wyers explained that the undergraduate program is an important step for those interested in doing graduate work in social services. "But don't be mislead; "wyers said, "social work is not fun."19

To further complicate matters, most graduate students feel they should be able to handle their own problems without help. Thomas taits about the price of this game playing activity:

... Much has been discrissed concerning the cultural "games played out during the act of living in an organized society. Graduate students and trainees in general seem especially vulnerable in feeling the need to play out these games. The goal is to project confidence and selff assurance; doubts and fears are tept hidden. Discarded and even false presentation of one's self protects an individual's unacceptable parts from visibility. Unfortunately, this "protection" comes at the high price of not letting other people into our real selves and even personally losing sight of whom we really are, thus loss of useful feedback and consequent development. ${ }^{20}$

19 "Scioool of Social Work 'Fastest Growing' at PSU," Vanguard, 7 May 1976, p.3.

20 Thomas, Sccial Worker as mrainer, p. 36. 
The Needs of Professionals

If student social workers are involved in the game playing of needing to appear self-confident by hiding personal doubts and fears, the game only changes form siightly upon gradiation. High turn-over rates in agencies and professional "burn-out" are problens cormon in professional practice.

Bob Czimbal is a yoga teacher who opened Cherry Grove Center (a growth-retreat center near Forest Grove, Oregon) in September 1975. He also has an undergraduate degree in social. work. Currently he is actively involved with teaching people what he calls, "self-survival skills" partially because in nearly twenty years of formal education, "no one taught me how to take care of myself," he explained. ${ }^{21}$

A similar viewpoint is expressed by Dave Skinner, a social worker at Clackanas County Children's Services. Part of his work as a suyervisor includes developing and conducting staff workshops each month on personal survival skil.ls. He explained that part of the reason he spends so much time doing the kinds of workshops he does is to help prevent burn-out among his staff members. Professional burn-out occurs, according to Skinner, when sociall workers have not learned to take care of themselves. He contends that "mental health professionals have to take care of themselves first or they won't be of any use to their clients. "22

\section{Implications for Curriculum Expansion}

The trend towards recognition of the need for greater personal

${ }^{21}$ Interview with Bob Czimbal, Portland, Oregon, 13 Aprii 1976. 22. Interview with Dave Skinner, Portland, Oregon, 21 May 1976. 
understanding and continued growth on the part of student social workers seems clear. The majority of social work courses continue to stress development of cognitive skills although students have identified the experiential parts of their courses to be the most helpful in developing empathic skills. 23

What value does experiential learning have for the student social worker and his future clients? How valuable is it for a student to have had the experience of being a participant in a therapy group or personal growth workshop? Should a student social worker be given credit for enrolling in a weight reduction program and losing twenty pounds over the term? What value could bioenergetics or Hatha Yoga have for the student specializing in social planning? These are a few of the questions graduate schools of social work must answer in the last half of the 1970 s to meet the needs of training for future professionals facing change.

${ }^{23}$ Kcefe, Empathy and Social Work Xducation, p. 69. 
CHAPTER II

RETEVANT EDUCATION: CHALIENGE OF THE FUTURE

When the person is guided by the real nature of his own experience, he also is genuinely present in his meetings with others. He is ready, as a whole person, to enter into the world of another person and to share his own resources and talents - not as a separate being, but in full commuion. Genuine relating is a process of intuitive awareness, sensing, and knowing - not an intellectual, objective, detached thought process which judges and classifies the other person. Genuine relating involves a recognition of the mystery and awe, the capriciousness and unpredictability of life. It means trusting unknown develcpments in experience and a willingness to follow the uncertain course that results in a creative realization of one's own potentialities.

-- Clark Moustakas ${ }^{24}$

\section{Trends in Graduate Education}

In 1969 Carl R. Rogers' controversial paper on graduate education appeared in his book, Freedom to Learn. In outlining what he calls a revolutionary program for graduate education Pngers has designed a program to facilitate greater leaming and creativity by emphasizing freedom and responsibility in the develcpment of the curriculum. 25

Rogers believes that the traditional, formal, rigid elucational system stifles creativity ard generates anxiety and irustration. Insteaü he proposes a program of independent study wivere each student contracts

24 Moustakas, Creativity and Conformity, p. 13.

${ }^{25}$ Carl P. Pogers, Freedom to Iram (Columbus, orio: Charles E. Merrill publishing company, 1969), pp. 183-202. 
for his individualzed learning experiences. Says Rogers:

The most socially useful learning in the modern world is the learning of the process of learning, a continuing openness to experience and incorporation into oneself of the process of change. . . If our present culture survives it will be because we have been able to develop individuals for whom change is the central fact of life and who have been able to live comfortabiy with this central fact. It means that they will not be concerned, as so many are today, that their past learning is inadequate to enable them to cope with current situations. They will instead have comfortable expectations that it will be continuously necessary to incorporate new and challenging learnings about everchanging si.tuations. 26

As a part of Rogers' innovative program, students would also have the opportunity to voluntarily join a basic encounter group with other students and faculty to increase self-atvareness ard to projide mutual feedback about individual strengths and weaknesses. 27

Although he has suggested that his curriculum design has implications for other graduate schools, Rogers prognan! was specifically developed to meet the needis of grauluate education in psychology. Duane Thomas has examined similar problems in the curiculum of graduate schools of social work. Ile sees the role of the social work educator as that of facilitator. As a facilitator the responsibility of the teacher is to aid the student in developing his fullest potential through a relationship which fosters authencity and mutual feedback. Thomas explains how this kind of a trairing program would have far reaching implications for social work practice:

The trainirig program, then, helps to allow the trainee latitude in truly being hinself. The alterrative to rigid, highly structured, preplanned trainer-dominated training is a joint,

$$
\begin{aligned}
& 26 \text { Ibid. , pp. 163-.164. } \\
& 27 \text { Ibid., p. } 195 .
\end{aligned}
$$


evolving program within a spontaneous "here and now" relationship, drawing up concepts and principles only as they relate to the actual learning process. In this respect. I have some question as to the usefulness of predeciding that: a trainee needs to learn how to interview, how to take social. histories, how to establish role perimeters, etc. The professional social worker uses himself: and his relationships to facilj.tate growth and development in individuals, groups, commurities, and bureaucratic organizations. He himself is his major instrument for change. In a society ever increasing in complexity the traditional modalities of casework, group work, and community organization must be expanded. We hear more and more of "versatility" in practice. The versatile social worker is a change agent, drawing upon a model which keeps human needs central while drawing upon a broad range of attitudes, ideas and skills, carried on within the "here and now" relationship. lost change systems cannot be preplanned; one must have full access to his personal resources on a spontaneous basis within a given situation. The ultimate practice is to flow with excitement, allowing one's full potential to be manifest. This demands confidence, awareness, and being truly in touch with the "now" circumstances. 28

The ability to flow with the continual changes in life means social workers must develop flexibility. Jois G. Swack has reported that " . . professional knowledge already has a half-life of only five years, with the likelihood that it will soon becone even shorter." 29 Under these circumstances she says," . . the most important thing professionals learn during their initial training is how to leam; they must have an intellectual fourdation that enahles them to learn and unlearn." 30

Two key complaints against traditional education have been noted by William Bridges:

- a) that it is prescriptively structured ("rinj is what you need to know and this is how to leam it" and b) that it is too exclusively cognitive in style and content "Eonget how you

28, Thomas, Social Worker as Trainer, p. 36.

29Tois G. Swack, "Continuing Eàucation and Changing Needs," Social Work (November 1975): 474 .

30 I.bid. 
feel about it, just get the information accurate"). ${ }^{31}$

Many a student during the course of his education finds that much of the material is meaningless. Too often formal education is a frustrating attempt to learn material that has little personal meaning for the student. According to Rogers, material that has only intellectual value ". . does not involve feelings or personal meanings; it has no relevance for the whole person." 32

The Contribution of Confluent Education

The value of experiential learning has been explored by George

Isaac Brown:

Simply stated, confluent education means combining thinking with feelings so that both benefit. Thinking is sometimes called the cognitive domain. Feelings and emotion fall in the affective domain. Confluent education seeks to integrate these two domains so they emerge to the extent that they both lose their boundaries and result in more holistic or "together" behavior on the part of the student. Instead of having motions clash or conflict with intellectual activity, we try to have both work in a harmonious relationship for the ultimate welfare and productivity of the learner . . .33

Beciuse confluence is an experience instead of another concept, it has both physiological and psychological correlates that can be identified and described. Thomas Yeomans further explains what happens when confluence occurs:

${ }^{31}$ William Bxidges, "Thoughts on Humanistic Education, or, is Teaching a Dirty Work?" The Journal of Humanistic Psychology (Winter 1973): $5-13$.

${ }^{32}$ Poogers, Freedom to Iearn, pp. 3-4.

${ }^{33}$ George Isaac Brown, The Live Classroam, ed. George Isaac Brown (New York: The viking Pxess, 1975), p. 3. 
Confluence is an experience that we all have in varying degrees of intensity, sometimes in learning situations, sometimes in relationships with other people, and sometimes when we least expect it. Always it yields new meaning and understanding that arise from seeing a hitherto hidden connection or relationship, and is accompanied by a release of energy, often manifested by excitement on the feeling level, a sense of significance and involvement, and on the nental level by increased conceritracion and mental functioning. It is very much akin to what in "creativitiy theory" is called the "aha" experience, the moment of insight and recognition when, after the coilection of experiences and a period of incubation or brooding over unrelated data, a pattern of organization suddenly iss seen, often in a "flash," and a new idea or poem or invention is conceived and then elaborated into final form. 34

Confluent education, then, provides a more balanced development of the student's personality through growth processes dealing with emotional, social, and moral maturity as well as intellectual devel-opment.

How Students Can Really Iearn

The professor's role, says Bridges, should be that of facilitator. The professor needs to be a genuine and unauthoritarian resource person who is available to help students learn what they want to learn. To be relerant, the curriculum must have real life application for the student. He explains:

- . The humanistic goal of self-knowledge and of what mmerson called "an original relation to the universe" can only be reached by providing people with several different kints of eciucational opportunities . . Profoundly alienated from ourselves, however, many of us do not yet know what we need, so we must devise ways in which to enable curselves to recover that experential center from which our own situations and their demands on us are re-

34tThomas Yeomans, "Search for a working Model: Gestalt, Psychosynthesis, and Confluent Education," in The Jive Classroom, ed. George Isaac Brown (New York: The Viking Press, 1975), pp. 135-136. 
vealed. To do this we must draw upon . . . the tradition that emphasizes nondirective assistance in discovering one's personal reality, and the tradition that emphasizes the masterly unfolding of new ways of doing and perceiving. . .35

If the social work practitioner is to feel confortable about allowing his clients the freedam to grow at their own rate it seems clear that he must first experience the kind of self confidence that comes through personal growth. Although Swami Brahmananda has wricten about spiritual teachers, what he says has application for both social work education and practice:

All that a teacher can do is inspire you. He cannot work for you. You have to do the work for yourself. A guru has understood the value of freedom. In the way that he gives this to you, he will be your spiritual teacher. He knows and loves his freedom. He is a gcod teacher, he is a real teacher, who helps you to be free.

A true guru is one whose consciousness is one with the whole universe. That is the reason, without imposing any of his own thoughts, he will just allow you to grow by yourself. Even if you want to attach yourself, he makes you free by giving you fullest knowledge, filling you with the spirit of freedon, confidence and hope. Thus he will inspire you and give you irpetus. The spiritual teacher does only that much, he helps you to grow by yourself. 36

The value of self growth is increasing in popularity within the Human Potential Movement. Each week thousands of people voluntarily join encounter groups like EST and Iifespring while others take Hatha Yoga classes, tai-chi, massage, and bicenergetics classes. The quest for purpose in life and escape from alienation in our highly mechanized and inpersonal scientific scciety attracts many to the growth movement. Unlike

35 Bridges, Is Teaching a Dirty Word?, p. 12.

${ }^{36}$ Swami Braimananda, "The Growth of Inner Strength," Yoga Journal (March-April 1976): 8 . 
traditional psychotherapy which is embedded in the medical model, the new growth groups hold the philosophy that "you don't have to be sick to get better." This philosophy recognizes the commonality in mankind and seeks innovative ways for people to feel better about themselves.

Why Encounter

What value do encounter groups have for student social workers? William C. Schutz has explained that through self-experience in an encounter group, people learn to be more of who they are:

Encounter i.s a mode of human relating based on openness, honesty, self-awareness, self-responsibility, awareness of the body, attention to feelings, and an emphasis on the here-andnow. It is a therapy in that it focuses on removing blocks to better functioning. It also has educational, recreational, and religious elements in that it attempts to create conditions leading to a more satisfying use of personal capacities. 37

Sensitivity training is one kind of encounter group used to assist. the student in his learning by allowing him to develop proressional skills without inhibiting his innate potential and creativity. Participation in sensitivity training sessions can also be effective in the development of empathic skills.

Additional skills available through active participation in sensitivity training are found in the definition given by Pallassana R. Balgopal. Sensitivity training is:

. . a process for improving self-insight, understanding of the conditions that facilitate or hinder group functioning, understanding of interpersonal operations in groups, and development of skills for diagnosing indiviciual, group, and organi-

37 William C. Schutz, "Encounter," in Current Psychotherapies, ed. Raymond Corsini (Itasca, Illinois: F.E. Peacock Publishers, Inc., 1973), p. 440 . 
zational behavior. 38

Several authors have suggested that students entering graduate school should be encouraged to join a sensitivity group. For a sensitivity group to be effective, however, participation must be voluntary. In addition to aiding in the development of authenticity in students and faculty alike; sensitivity training is likely to have the following benefits for participating students Balgopal has found:

Sensitivity training can aid students in overconing the anxieties associated with a process-oriented concept of education . . even highly motivated students experience a sense of loss in giving up old ideas, feelings, and patterns, especially when the new learning is not yet incorporated . . Participation in sensitivi.ty training groups holds potential for giving the individual student peer-group support and opportunity to voice his emotional struggles as he begins to cope with neN ideas and conflicts associated with his new role. 39

\section{Toward Curriculum Expansion}

Involvement in an encounter group throughout graduate school is one way students can begin to help create a more relevant, changeoriented curriculum. Another way would be to introduce a large variety of the new psychological techniques and body therapies into the core curricuilum offered curing the student's first term of school. Following this basic introductory course, students would be encouraged to choose from fifteen or twenty possible growth-oriented groups to join for one of their elective classes each term. It the end of each term students could write a paper about how the particular personal growth

38pailassana R. Palgopal, "Sensitivity Training: A Conceptual Nodel for Social hork Education," Journal of Education for Social Work (Wirter 1.974): 6 .

${ }^{39}$ Ibid. 
class would be useful in professional practice. This increased emphasis on self-awareness through personal participation in growth groups will begin to allow social workers to finally be an active part of holistic social work education. 
CHAPTER III

MTND-BODY-SPIRIT

Be concerned with the development of the whole person. This maxim is compatible with an organixmic, wholistic approach to people. It suggests that education be neither purely connitive, more affective, purely theoretical, nor purely practical. - . this maxim suggests that the teacher attenpt to structure educational experiences so that overall there is no undue emphasis on one kind of learning at the expense of others. The net result of this attitude is the maximal development of the whole person.

-. Charles M. Rossiter, Ir. 40

\section{Holistic Eâuation}

For the purpose of this paper holistic education will be defined as those processes that work toward integrating both cognitive and affective learning for the development of the mind, body, and spirit within the student.

A Holon

Arthur Koestler has given the following definition of a holon: ". . like the god Janus, a holon faces two directions at once -- inward toward its own parts, and outward to the system of which it is a part . . "4l Anderson and Carter have further explained how a holon

40 Charles M. Rossiter, Jr., "Maxims for Humanizing Education," Journal of Humanistic lsychology (Winter 1976), p. 76.

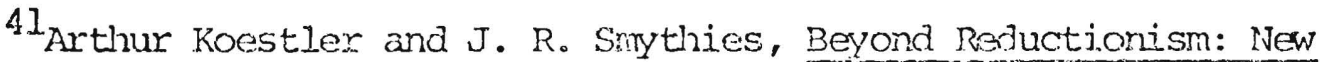
Perspectives in the Jife Sciences, quoted in Ralph E. Anderson and Irl E. Carter, Human Behayior in tie Social Ervironment, (Chicago: Aldine Publishing Company, 1974), p. 9. 
functions :

- . each social entity, whether large or small, compless or simple, is a holon. The term is borrowed from Arthur Koestler who coined it to express the idea that each entity is simultaneously a part and a whole. The unit is made up of parts to which it is the whole, the suprasystem; and, at the same time, is part of some larger whole of which it is a component, or subsystem - . What is central is that any system is by definition both part and whole . . No particular system is determinant, nor is system behavior determined at any one level, part or whole. 42

Natural-System Model

The holistic education model presented in this paper is similar to the "natural-system model" explained by Gouldner:

The natural-system model regards the organization as a "natural whole." The realization of the goals of the system as a whole is but one of several important needs to which the reorganization is oriented. . .

Organizational structures are viewed as spontaneously and homeostatically maintained. Changes in organizational patterns are considered the results of cumulative, unplanned, adaptive responses to threats to the equilibrium of the system as a whole . . .

The focus is not on deviations from rationality but, rather, on disruptions of organizational equilibrium . . .

The natural-system model is typically based upon an underlying "organismic" model which stresses the interdependence of the component parts. 43

\section{Holi.sm and Social Work}

Social work has traditionally had (as its strongest distinguishing

factor from other helping professions) the view of the total person as he functions within the larger enviroment. "Social work," Gordon Hamilton has said, "is, perhalss, the only profession in which involvoment of the

12 Ralph E. Anderson and Irl E. Carter, Human Behavior in the Social Environment (Chicago: Nldine Publishing Company, 1974), p. 9 .

${ }^{43}$ Ibid. , p. 62. 
whole person within the whole situation is the goal and process." 44

Examples of this holistic apprcach conmon in current social work practice include community organization, family and network therapy. On an interdisciplinary team, the medical or psychiatric social worker has always been responsible for relating how the patient's home environment will affect his prognosis. The individual is viewed as part of the larger whole of which he is a part.

In order for the social worker to inosrporate a holistic philosophy into his professional practice, he must first begin with himself. This cormon-sense philosophy is rarely practiced in graduate schools or even discussed in social work classes. Although self-knowledge is listed on the bottom of the list of principles of social work, no methods for attaining such knowledge are delineated throughout professional training.

In his book, Zen and the Art of Motorcycle Maintenance, Rohert M. Pirsig gives us clues about why the social worker needs to consider himself a vital part of the whole picture before he enters into any helping relationship. Pirsig is not just talking about repairing motorcycles when he says:

. . You've got to live right too. It's the way you live that predisposes you to avoid the traps and see the right facts. You want to know how to paint a perfect painting? It's easy. Make yourself perfect and then just paint naturaily. That's the way all the experts do it. The making of a painting or the fixing of a motorcycle isn't separate from the rest of your existence. If you're a sloppy thinker the six days of the week you aren't working on your machine, what trap avoidances, what gimmicks, can make you all of a sudden shaip on the seventh? It all goes

${ }^{44}$ Gordon Harnilton, "The Role of Casework in Social Policy," quoted in Mary J. McCormick, Social. Advocacy: A New Dimension in Social Work, ed. Ellen Manser (New York: Family Service Association of America, 1973), 109-126. 
together. . .

- . The real cycle you're working on is a cycle called yourself. The machine that appears to be "out there" and the person that appears to be "out there" and the person that appears to be "in there" are not two separate things. They grow toward Quality or fall away from Quality together. 45

By providing self-growth courses as part of the curriculum for each term throughout graduate school, the social workers of the future will be better equipped to first successfully adjust to the many changes in their own lives. In this way they can more effectively share their knowledge with their clients and fellow professionals.

\section{Mind-Body-Spirit}

The appreciation of the interconnectedness of the mind, body and spirit within all people needs greater emphasis in professional education.

In grade school, junior high and high school and the first years of college some emphasis is placed on the physical development of children and young adults necessary to accompany the acquisition of cognitive skills. The Presicent's Physical Fitness Program attests to this need for developing physical abilities. Attention to spiritual development is usually provided through fomal churches during this time as well. As the child grows older, however, less and less significance is placed on individual physical development with the exception of hoys who engage in competitive sports. Many continue to attend the church of their choice while other young adults abandon formalized religion because

45 Robert 11. Pirsig, Zen and the Art of Mtorcycle Maintenance (New York: Bantam Books, 1974), pp. 318-319. 
it has little relevance for their everyday experiences.

By the time the adult reaches graduate school, no credits are given to students who want to continue with their physical development. The philosophy of our society seems to be that it is good for growing children to play and exercise their bodies; but grown-ups certainly have little need for such activities. Forty hours of work each week coupled with evenings at home in front of the televeision set with beer and cigarettes for company is the all too typical picture of our physically unfit adult society.

The body contains the entire history of a person. The body is the storehouse for trauma, blockages and limitations. Strong, flexible muscles indicate those muscle parts that are developed and function well. Neglect at some point in life is reflected by the undernourished parts of the body. 46

In explaining hơ physical and emotional trauma and limited use prevent: nomal developnent, Schutz has said:

The body develops to the degree that it is used, to the degree that it completes energy cycles. The more of these completed the more highly realized is the person. The three blockages slow the flow and build blocks into the physical structure. These blocks diminish the physiological functioning leading to reduced blood supply, less oxygen, impeded nervous impulses, reduced organ function, diminished intellectual capacity and eventually physical and emotional illness. 47

The importance of "centering" in everyday living is also explained by Schutz:

${ }^{46}$ Schutz, Encounter, p. 412.

47 Ibid., pp. 413-414. 
In the interaction between a person and his body, the control problem is one of centering. A body undercontrolled is disorganized; a bociy overcontrolled is rigid. A well-controlled body functions with integration among its parts so that they flow easily and appropriately. Inappropriate movement and coordination result when the body is uncertain of what it is doing. Centering means placing everything in its appropriate place so that one is "hooked-up." Being off-center makes all moverient slightly disconnected. 48

Because the body, mind, and spirit are so intimately related, improvement in bodily functioning, for instance, can also improve mental acuity. By learning one of the techniques listed below (or numerous others) students can learn valuable ways to share personal growth with clients in a therapeutic situation.

1. Psychosynthesis

Growth techniques that prove most effective work on several aspects of the person during the same time period. Psychosynthesis is one of the few approaches that has developed techniques for developing the mental, physical, and spiritual sides of man simultaneously. The vast range of techniques available (e.g. creative movement, guided imagery, meditation, gestalt, symbolic art and journal keeping) help assure the practitioner will not get caught in the professional trap of "falling in love" with one psychological technique to the point that all others are exciuded. The founder of this unique approach, Roberto Assagioli, has said:

\footnotetext{
- psychosynthesis can be epplied by the individual himself or herself, sostering and accolerating inner growth and self-artualizatzoil, which should be the aim of all and which somerimes is seif as an imperative inner urge, as a vital existentjai necessity. Such self-psychosynthesis should be
}

$$
{ }^{48} \text { Ioid. , p. } 4 \mathrm{ij} .
$$


practiced, or at least seriously attempted, by every therapist, social worker and ecucator (including parents). . .49

Thomas Yeomans has explained that Psychosynthesis:

- . has recently become known in this country as a comprehensive and effective therapeutic theory and practice, based on a conception of man as being in the process of personal growth, whose personality can be organized around a center of awareness and energy -- first in the personal self and then in the transpersonal self. This center is conceived of, and can be experienced by man, as a focal point from which, through the identification of an awareness of it and the disidentification from any other aspect of the personality, we can regulate, ciirect, harmonize, and integrate the many elements within our psyche. This, in turn, leads to a more highly integrated and effective life activity and experience.

2. Gestalt Therapy

Over the past few years gestalt therapy has gained increased acceptance within the social work profession. Gestalt therapists will usually point to theix ow experience in therapy as the best way to learn how to be an effective therapist. Thomas Yeomans has written:

Gestalt therapy, which was developed by Frederick perls as a reaction to traditional psychoanalysis, draws upon existential phenomenoiogy for its philosophical bases, and works to develop a person's awareness of his present experience. It holdis that all clues to a patient's cure lie in here-and-now behavior, and that by accepting, exaggerating, and exploring this behavior and expexience, a person can get in touch with, and work through, emotional conflicts or blocks that are preventing his growth and further developmenc. A wide range of awareness techniques are used in this work and its basic aim is to restore to a person his potentially "whole" or integrated personality, unassailed by

\footnotetext{
${ }^{49}$ Roberto Assagioli, Psychosynthesis (New York: The Viking Press, 1.965), p. 9.

50Yeomans, Searci: for a Working Model, p. 139.
} 
severe emotional conflicts or spiits. The basic intent of Gestalt is to enable a person to live as rich an emotional life as possible, and to help him allow emotional experierice to occur without trying to control and/or avoid it through fantasy, intellectualization, muscle contraction, or projection. It conceives of the personality basically as a flow of life. energy through the organism which, when it becomes blocked, can be freed again through the use of awareness, present-experiencing, and working and projections, introjections, and retroflections. The basic aim of Gestalt therapy is emotional growth. 51

\section{Hatha Yoga}

The ancient proctice of Yoga recognizes the need for discipline in the development of the whole psychophysical self. Severin Peterson has explained that Yoga:

- . develops forces that are already within you. Beginning with improved health and added physical well-being, it works up slowly through the mental to the spiritual. The transition is so gradual that you may not even be aware of it until you realize that whange in you has already taken place. 52

Hatha Yoga stresses insistence upon the basic importance of the body. ". . . Its way of exercising and concentrating eventually results in a corplete restructuring of one's skeletomuscular form as well as circulation, respiration, and the other major body sytems." 53

Through Hatha Yoga the student learns to continually advance to his edge which extends always outward toward greater openness and flexibility. Greater ontrol of the body coupled with relaxation leads to effecting control of the mind. The utilization of proper breathing exercises helps the student beoome more proficient in his asanas (physi-

${ }^{51_{\text {Ibi.d. , po. }} 138-139 .}$

52 Severin Peicerson, A Catalog of the Ways People Grow (New York: Ballantine Books, 1971), p. 279 .

53 trid., p. 150. 
cal postures practiced to strengthen and expand the body).

\section{Breathing Therapy}

The breath is considered to be the life force, or Pranayana, in the practice of Hatha Yoga. Correct breathing is also an integral part of Fikido and I'ai Chi Ch'uan. The benefits of breathing therapy are many:

There is more involved than the movement of the breath. Muscles which have been only mechanically manipulated to walk or talk can be brought into consciousness as distinct and individual. Muscles which have been too tight and numb to sense loosen enough to allow the nervous system to function more freely; muscles which have been too lax can, through use, begin to build new tissue and hense[sic] new sensation. It happens gradually, slowly. The whole tonus of various regions of the body changes, enlivens. 54

The breathing function is also valuable because of its intimate connection with the emotions and both the autonomous and voluntary nervous systems. Peterson explains, ". . The breath thus foms a bridge between the conscious and unconscious systems. By watching it, one can observe an unconscious function at work, learn to exclude interferences, and he?p sulf-regulating processes ser in. . . ."55

\section{T'ai Chi Ch'uan}

Correct breathing must be coordinated with the movements of T'ai Chi Ch'uan. A relaxed hody and calm but concentrated mind are essential to obtain Whe hamany that is the esserice of T'ai chi Ch'uan. Scmetimes caller? meditation in motion, T'ai Chi Ch'uan poerates by utilizing the forces of Yin (the passive principle) and Yang (the active principle)

$$
\begin{aligned}
& { }^{54} \text { Ibid., p. } 56 . \\
& { }^{55} \text { Ibid., p. } 58 .
\end{aligned}
$$


in active interplay.

Peterson explains what happens through the practice of $\mathrm{T}^{\prime} \mathrm{ai}$ Chi Ch'uan:

- With the techniques of T'ai Chi Ch'uan, true energy can be controlled, strength balanced, and vitality increased, by using the body in such a way so as not to strain the muscles, not to over-activate the heart, not to exert oneself excessively. It is the philosophy of 'm'ai Chi Ch'uan that in order to prolong the life of the bociy, to stabilize the life of the emotions, and to intensify the life of the mind, conscious cooperation of the mind with activity is a deep necessity. For certainly peace of mind cannot be attained without use of the mind. The consideration of man's total health as an inseparable unity is evident in every movement of this long, slow exercise. 56

\section{Aikido}

T'ai Chi Ch'uan has been referred to as "the mother of the oriental martial arts."57 Aikido operates on the principle that the mind leads and the body follows:

Its outstanding feature is that it made a great leap from the traditional physical arts to a spiritual martial art, from a relative martial art to an absolute art, from the aggressive, fighting martial arts to a spiritual martial art that seeks to abolish conflict. 58

This philosophy can be practiced because in Aikido the goal is not to conquer an enemy, but to conquer oneself. Through work on oneself, Aikido practice trains the mind, improves personal health, and develops increased self-confidence.

\section{Meditation}

Although T'ai Chi Ch'lian has been called a moving meditation, gen-

56.Jbid., p. 258.

${ }^{57}$ Tivid., p. 262.

${ }^{58}$ Ibid., p. 1. 
erally people think of meditation as a passive activity. Probably the most popular form of meditation today in Western society is Transcendental Meditation. In the practice of IM, each student is given a sound suited to his temperment called a mantra. After some initial instruction, the student is to say the individualized mantra to himself in a quiet place for fifteen minutes twice each day. The lasting benefits of TM include the following:

- . Researchers have reported that regular practice of the technique improves leaming ability, perceptual motor performance and reaction time. Other researchers have noted improved psychological health, improved ability to recover from stress, and improved perceptual acuity. Management scientists have reported that the TM program increases productivity and job satisfaction. Doctors have reported that the TM program reduced high blood pressure, improves asthmatic conditions and is useful treating the mentaliy ill . . 59

While IM is restricted to a seated meditation twice daily, the object of both Zen Meditation and Yoga Meditation is ". . to deepen one's way of being so that one can meditate all day, whether walking, talking or writing letters."60

Meditation has special value for artists, philoscphers and scientists because it is said to be the higher phase of concentration:

- . Ey developing a higher power of concentration, they gain the ability to marshal theix thought enerory toward a particular object or phenomenon. But eventually their uninterrupted flow of thought may result in a sudden flash of intuition, illuminating the essential stmucture of the object of meditation. The flash of intuition coincides with the moment of their complete absorption in the object with an intimate sense of oneness with

${ }^{59}$ Bloomfield et al., Thi: Discovering Inner Energy, p. 32.

60peterson, ways People Grow, p. 164. 
its inner essence. . .61.

\section{Inner Imagery}

Artists and other creative people have found the use of inner imagery to be an effective problem-solving technique. Some people see the images with their eyes open while others find it easier to form images with closed eyes. In a problem-solving situation some poeple:

will form a picture in their mind of the form or objects they are working with and then let their imagination change these forms in different ways . . With active imagination, the act of seeing with the inward eye is deliberately willed. . .62

In comparing inner imagery to dreaming, the following differences have been noted:

- . Whereas the dream expresses the standpoint of the unoonscious only, active imagination apparently presents something more in the nature of a synthesis of the conscious and the unconscious standpoints. Because of this, although such visions are expressed in the same picture--language as the dream, they are, nevertheless, nearer to consciousness, and as such more readily interpreted. 63

\section{Structural Integration}

For those students who want a more rapid system for restructuring the body than llatha Yoga, structural integration was created by Dr. Ida Rolf. The ten-session rolfing series is ". . a method of integrating the body structure through physicai repositioning of tense muscles and fascia. . . 64

$$
\begin{aligned}
& \text { 6lIbid. , p. } 167 . \\
& 62 \text { Ibid., p. } 161 . \\
& 63_{\text {Ibid. , p. } 162 .} \\
& { }^{64} \text { Schutz, Encounter, p. } 403 .
\end{aligned}
$$


An explanation of what occurs through the process of structural integration is explained by Peterson:

Rolf processing results in a reawakening. Through releasing chronically contracted muscles and letting the body move back toward its natural symetry, the physical basis of experience is unblocked. Breathing becomes free again delicately responsive to the inmediate situation. The metabolism of the muscles and of the entire body reenergizes. . .

Muscle tissue, fomerly nonelastic, is released and repositioned, thickened tissue is energized, resulting in a new pattern of body movement. Pepair of tissue occurs spontaneously as the body is brought to balance. Muscles seem to expand as they are released. Bolf processing guides the structure toward its natural alignnent, toward a natural three-dimensional symmetry, toward balance. 65

Rolfers do not deny that there is usually some pain involved in this process of restructuring underlying tissue. This pain of growing means: ". - there are times when sexual, aggressive, spiritual overtones blend with the joy of feeling regions of the body release and fill with sensation-feeling and a new awareness of connecteriness and strength." 66

10. The Feldenkrais Method

Freeing the body from rigid, and therefore limiting patterns, is the goal of Woshe Feldevkrais. His exercises demonstrate that:

- - by practiciag urusual movements we senci neiv messages to the nervous systen that allow the nervous system to send new messages to the body to jelease some of the built-in restrictions and allow the bociy more freedom and mobility. Aing with the new bocil freeciom many subjects report a feeling of psychological loosening. 67

\footnotetext{
65Peterson, Ways PEople Grow, pp. 250-251.

66 Ibid. , p. 252.

67 Schutz, Encounter, p. 410.
} 
William Schutz explains the philosophy behind the development of this method:

A person whose body functioning is limited, in the Feldenkrais sense, may have gotten that way through social pressure, or through lack of an imaginative and challenging environment . . . Because social taboos prohibit moving the pelvic area either forward and backward or sideways, the flesh around the pelvis builds up and sits without movements. So the hips and upper legs become large out of proportion to the rest of the body, with a buildup of fatty tissue, usually softer, flabbier, whiter, and cooler than the surrounding tissue due to diminished blood flow. 68

Feldenkrais exercises also include an ideational component. After completing some physical movements several times, the student closes his eyes and visualizes the same movements being performed several times. This use of active imagination aids in the proficiency of the movenents and increases flexibility upon actual performance. 69

\section{Bioenergetics}

While rolfing deals only with a single postural ideal in the restructuring process; bioenergetics includes greater recognition of individual differences in body types and life styles. According to a vell-known bioenergetics therapist, stanley Keleman, bioenergetics teaches people how to lose control by kicking, screaming, and yielding to involuntary pulsations of their bodies. Keleman says bioenergetics ". . is proposing an energetic theory of reality which unites body and mind."70 The goals of bioenergetics as practiced by Keleman are:

${ }^{63}$ Ibid., p. 412 . 69Ibid., p. 411. 70 Keen, Sam, "We Do Not Have Eodies, we Are Our Bodies," Psychology Today, September 1973, p. 66 . 
I define my goal as embodiment or self-formation. Every organism goes through certain stages. Iife goes from a state of universal oneness, to a state of expansion, to a state of setting up boundaries to contain energy, to a state where the boundaries are broken and the life energy goes back into the universal pool. This is death, symbolic or real. our selfknowledge forms boundaries which contain our energy and give us definition, but when we act, or the world acts on us, we break down our boundaries and expand our sphere of being. Until actual death, we are always breaking and reforming our boundaries. I want a person to develop a sense of identification with all aspects of his biological processes: feeling, sensing, thinking and action. Both containment and expression, tension and relaxation are necessary for an organism to be flexible, graceful, and in contact with itself. . . Increase in the ability to feel is a good compensation for an overdevelopment of the mind, but thought and action are important aspects of the healthy organism. 71

Growth and the Graduate Curriculum

Throughout graduate school a variety of personal growth courses needs to be available for elective credit to those social work students who wish to expand their personal awareness.

During the first term, ten or twelve teachers can be invited to speak to the first year students during their core curriculum class. Some of the teachers may wish to give demonstrations of their techniques and answer questions at this time. In this way, students will have a broad-ranged exposure to psychophysical techniques and be able to ascertain which ones are likely to fit their own personal growth needs.

For each successive term in school the student would be able to participate in a personal growth experience for elective credit.

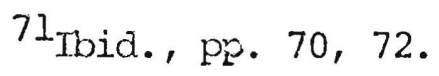


Students may also wish to participate on a voluntary basis in an ongoing sensitivity group as part of their graduate studies.

The coriponents of a growth-oriented graduate school curriculum in sumation include: (1) a variety of growth-oriented courses offered each term for interested students; (2) voluntary participation in all of the courses; (3) encouragement and involvement of faculty in these growthrelated courses; and (4) elective credit granted each term for participating students.

The personal benefit of active participation in classes geared toward personal growth can have broad-ranged impiications for assisting clients who are experiencing problems in living. To be effective agents of change, sccial. workers must first realize that lasting change occurs from within. 
SOURCES CONSULTED

Anderson, Ralph E. and Carter, Irl E. Human Behavior in the Social Environment. Chicago: Aldine Publishing Company, 1974.

Anderson, Walt. "Pas De Psyche." Human Behavior, March 1975, pp. 56-60.

Armitage, Andrew and Frank W. Clark. "Design Issues in the PerformanceBased Curriculum." Journal of Education for Social Work 11 (ivinter 1975) : 22-29.

Assagioli, Roberto. Psychosynthesis. New York: The Viking Press, 1965.

, "Psychosynthesis: A Technique for the Use of Intuition," In

The Nature of Human Consciousness, pp. 336-342. Edited by Robert E. Ornstein. New York: The Viking Press, 1973.

, The Act of Will. Baltimore: Penguin Books, Inc., 1973.

Balgopal, Pallassana. "Sensitivity Training: A Conceptual Model for Social Work Education." Jourmal of Education for Social Work 10 (Spring 1974): 5-11.

Block, Alvan M. "The Dilerma of Social Work Education: Restructuring the Curriculum." Journal. of Fducation for Social Work 8 (Winter 1972) : 19-23.

Bloomfield, Harold H.; Cain, Michael Petex; Jaffe, Dernis T.; and Kony, Robert B. TM: Discovering Inner Energy and Overcoming Stress. Ner York: DEll Publishing Co., Inc., 1975.

Boehm, Werner W. "Social. Work Education: Issues and Problems in tight of Recent Developments." Journal of Education for Social Work 12 (ivinter 1976): 20-27.

Bralumanamda, Swami. "The Growth of Inner Strength," Yoga Journal 2 (March-April 2976): 8, 13.

Bridges, William. "Thoughts on Humanistic Education, or is Teaching a Dirty Word?" The Journal of Humaristic Psychology 13 (Winter 1973) : $5-i 3$. 
Brown, George Isaac. Human Teaching for Human Learning. New York: The Viking Press, 1971.

, The Live Classroom. New York: The Viking Press, 1975.

Copeland, Paul. "Yoga, Mind and Muscle." Yoga Journal 2 (March-Ipril 1976) : 27-28.

Czimbal, Bob. Portland, Oregon. Interview, 13 April 1976.

Goleman, Daniel. "Meditation Helps Break the Stress Spiral." Psychology Today, February 1976, pp. 82-86, 93.

Hamilton, Gordon. "The Role of Social Casework in Social policy." Quoted in Mary J. MaCormick, Social Advocacy: A New Dimension in Social Work, pp. 109-126. New York: Family Service Association of America, 1973.

Jackson, Ian. Yoga and the Athlete. Mountain View, California: World Publications, 1975.

Jacobs, Jane. "More Thoughts on the Teacher-Student Relationship: The Crisis As An Aspect of Change." Yoga Journal 2 (March-April 1976): 23-25.

Keefe, Thomas. "Empathy and Social Work Education: A Study." Joumal of Education for Social Work ll (Fall 1975): 69-75.

Keen, Sam. "We Do Not Have Bodies, We Are Our Bodies." Psychology Today September 1973, pp. 65-73, 98.

Koestler, Arthur, and Smythies, J.R. Beyond Reductionism: New Perspectives in the Life Sciences, guoted in Palph E. Anderson and IrI E. Carter, Human Behavior in the Social Enviroment, p. 9. Chicago: Aldine Publishing company, 1974.

Ieonard, George B. The Transfornation. New York: Delacorta Press, 1972.

LeShan, Lawrence. How to Meditate. New YOrk: Bantam Books, 1974.

Lowen, Alexander. Pleasure. New York: Penguin Books, Iric. 1970.

May, Rollo. Love and will. New York: Dell Publishing Co., Inc., 1969. , Man's Search For Himself. New York: Signet Books, 1953.

Mayer, John $\mathrm{E}_{\text {. }}$ and Rosenblatt, Aaron. "Sources of Stress Among Student Practitioners in Social work: A Sociological View." Journal of Education for Social Work 10 (Fall 1974): 54-66. 
Metz, Geri. "Gestalt and the Transformation." In The Live Classroom pp. 19-20. Edited by George Isaac Brown. New York: The Viking Press, 1975.

Miller, Don Ethan. Bodymind. New York: Pinnacle Books, Inc., 1974.

Mishra, Rarmurti. Fundamentals of Yoga. New York: Lancer Books, 1959.

Moustakias, Clark. Creativity and Conformity. New York: Van Nostrand Reinhold Company, 1.967.

Muramota, Naboru, Healing Ourselves. New York: Avon Books, 1973.

Narboe, Nan. Portland, Oregon. Interview, 24 May 1976.

Norwook, Jr., W.D. The Judoka. New York: Alfred A. Knopf, 1973.

Oyle, Irving. The Healing Mind. Millbrae, California: Celestial Arts, 1975.

Peterson, Severin. A Catalog of the Ways People Grow. New York: Ballantine Books, 1971 .

Pirsig, Robert M. Zen and the Art of Motorcycle Maintenance. New York: Bantam Books, 1974 .

Rogers, Carl R. Freedom to Learn. Columbus, Ohio: Charles E. Merrill Publishing Company, 1969.

Rossiter, Jr., Charles M. "Maxims for Humanizing Education," Journal of Humaristic Psychology 1 (Winter 1976): 76.

Rubin, Jerxy. "From the Streets to the Body," Psychology Today, (September 1973/po. 70-71.

"School of Social Work 'Fastest Growing' at PSU." Vanguard. p. 3.

Schutz, William C. "Encounter," Current Psychotherapies, pp. 401-443. Edited by Raymond Corsini. Itasca, Illinois: F.E. Peacock Publishers, Ine., 1973. , Here Comes Everybody. New York: Harper \& Fow, Publishers, 1971.

Selye, Hans. Stress Without Distress. New York: Pinnacle Books, Inc., 1974.

Skinner, Dave. Portland, Dregon. Interview, 21 May 1976.

Stevens, John O. Awareness: Exploring, Fxperimenting, Experiencing. Layfayette, California: Real people Press, 1971. 
Swack, Lois G. "Continuing Education and Changing Needs," Social Work 20 (November 1975): 474-480.

Thomas, Duane. "The Social Worker as Trainer.: In Social Workers As Trainers in Health Programs, pp. 32-41. Edited by Laura Bertino and Robert C. Jackson. Berkeley, California: University of Califormia, 1972.

Toffler, Alvin. Future Shock. New York: Bantom Books, 1970.

Tropp, Fmanuel. "Approaching the Concept of Change in Education for Social Work," Journal of Education for Social Work 9 (Spring 1973): 99-106.

Walker, Walter L. "Changing Thought and Action Styles of Students and Facuity: Imperatives for Social Work Education?" Journal of Education for Social Vork 3 (Winter 1972): 56-63.

Weil, Andrew. The Natural Mind. Boston: Houghton Mifflin Company, 1972.

Wilson, Colin. New Pathways in Psychology: Maslow and the Post-Freudian Revolution. NEW York: Signet Books, 1972 .

Wright, Thomas J. Portland, Oregon. Interview, 22 May 1976.

Yeomans, Thomas. "Searching for a Wowting lodel: Gestalt, Psychosynthesis and Confluent Ld:acation," In The Live Classroom, pp. 132158. Edited by George Isaac Brown. New York: The Viking Press, 1975. 